\title{
Can Mental Index be used on CBCT images to determine sexual dimorphism?
}

\section{O Índice Mentual aplicado em imagens de TCFC pode ser utilizado para determinação do Dimorfismo Sexual?}

\author{
Ana Luiza Esteves CARNEIRO1 iD https://orcid.org/0000-0002-3799-5043 \\ Sabrina Evelyn Santos MACIEL' ${ }^{1}$ iD https://orcid.org/0000-0002-8333-2312 \\ Daniela Miranda Richarte de Andrade SALGADO1 (iD https://orcid.org/0000-0003-4646-7389 \\ Jéssica Rabelo Mina ZAMBRANA ${ }^{1}$ iD https://orcid.org/0000-0003-2072-9192 \\ Nataly Rabelo Mina ZAMBRANA1 ID https://orcid.org/0000-0002-5516-9810
}

Claudio COSTA 1 iD https://orcid.org/0000-0003-2831-8670

\section{ABSTRACT}

Objective: Radiomorphometric indices (RI) vary according to gender and age. The objective of this study was to assess bone quality in men and women, using tomographic images. Methods: A total of 78 Cone Beam Computed Tomography (CBCT) images of female and male patients were analyzed. The images were obtained from LAPI-FOUSP database, São Paulo, Brazil, and the Mental Index, which is a quantitative index, was evaluated on those images. The images were divided into 2 groups: Group M - Men and Group W - Women and evaluated by one examiner in two different times (T1 and T2). The data was submitted to a statistical analysis with a $95 \%$ level of significance $(p<0.05)$. Results: The ICC tests showed an average to good intra-examiner agreement. The age averages were: $48.46 \pm 15.3$ for group $\mathrm{W}$ and $53.87 \pm 13.09$ for group $\mathrm{M}$. On the Ml evaluation, statistically significant differences were observed between the two groups. Conclusion: We concluded that Ml can be used to determine sexual dimorphism, once the thickness of the mandible cortex in women is smaller than the thickness found in men.

Indexing terms: Cone-beam computed tomography. Radiology. Sex characteristics.

\section{RESUMO}

Objetivo: Avaliar o dimorfismo sexual, por meio da aplicação de IR em imagens tomográficas. Métodos: Foram analisados 78 exames de tomografia computadorizada de feixe cônico (TCFC), de pacientes do sexo feminino e masculino. As imagens foram obtidas do banco de dados do LAPI-FOUSP, São Paulo, Brasil, e por meio delas o Índice Mentual, que é um IR quantitativo, foi avaliado. As imagens foram divididas em 2 grupos: Grupo $M$ - Homens e Grupo W - Mulheres e avaliadas por um examinador em dois tempos diferentes (T1 e T2). Os dados foram submetidos a análise estatística com nível de significância de 95\% $(p<0,05)$. Resultados: 0 teste ICC mostrou

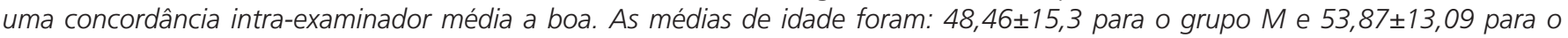

\footnotetext{
1 Universidade de São Paulo, Faculdade de Odontologia, Departamento de Estomatologia. Av. Prof. Lineu Prestes 2227, Butantã, 05508-000, São Paulo, SP. Correspondência para / Correspondence to: ALE CARNEIRO E-mail: <ana.esteves.carneiro@usp.br>.

Carneiro ALE, Maciel SES, Salgado DMRA, Zambrana JRM, Zambrana NRM, Costa C. Can Mental Index be used on CBCT images to determine sexual dimorphism?. RGO, Rev Gaúch Odontol. 2020;68:e20200026. http://dx.doi.org/10.1590/1981-863720200002620180072
}

$\nabla \nabla \nabla \nabla$ 
grupo H. Na avaliação do IM, foram observadas diferenças estatisticamente significantes entre os dois grupos. Conclusão: Concluímos que o Índice Mentual pode ser utilizado para determinar o dimorfismo sexual, uma vez que a espessura da cortical da mandibula nas mulheres é menor que a espessura encontrada nos homens.

Termos de indexação: Tomografia computadorizada por Raios X. Radiologia. Caracteres sexuais.

\section{INTRODUCTION}

In imaging studies, radiomorphometric indices (RI) are used to evaluate bone morphology, on both qualitative and quantitative ways, and consists in the application of different indices on the radiographic image. These indices are based mainly on measurements of cortical bone since it is more easily observed in radiographs than the trabecular bone [1].

Studies have reported that the thickness of the mandible cortex measured on panoramic radiographs correlated with the Bone Mineral Density (BMD) of the lumbar spine and the proximal femur, assessed by the goldstandard examination, X-ray dual energy absorptiometry, also known as bone densitometry (DEXA) $[2,3]$.

Currently, research is being done on the application of radiomorphometric indices (RI) on Cone-Beam Computed Tomography $(\mathrm{CBCT})$, since the oral rehabilitation through dental implants has gained strength, and the requisition of this exam has increased significantly $[4,5]$. Koh \& Kim [6] conducted a study to evaluate the use of Computed Tomography Indices (CTI), based on panoramic mandibular index (PMI), using CBCT images to evaluate the BMD of postmenopausal osteoporotic women. They concluded that it is possible to diagnose bone alterations in women using CBCT images using CTI.

The authors could not find in the literature studies assessing sexual dimorphism through the application of $\mathrm{RI}$ on panoramic radiographs and on CBCT. This is of great importance in forensic research, mostly on cases where skull fragments are unlikely to be identified based on the dental arch. In such cases, determining the sex is imperative to instantly rule out several possibilities, as well as help establishing a biological profile of human remains, and thus to get closer to a compatible identity [7].

The aim of this study was to evaluate the possibility of determining sexual dimorphism through the application of RI on CBCT images.

\section{METHODS}

This project was approved by the research ethics committee of University of Sao Paulo School of Dentistry $\left(n^{\circ} 658.977\right)$.

\section{Sample selection}

A total of 78 CBCT examinations of the jaws, belonging to the LAPI-FOUSP archive, were used. The images were acquired on iCAT Classic ${ }^{\circledR}$ equipment (Kavo, USA), and panoramic reconstructions with $20 \mathrm{~mm}$ of thickness were used. The examiner had access only to the gender and age of each individual.

Subjects were divided into two groups:

- Group W - 39 women aged between 20 and 75 years.

- Group M - 39 men aged between 20 and 75 years.

\section{Mental index}

The Mental Index (MI) evaluated the thickness of the mandible cortex bilaterally. A line that passed through the center of the mental foramen and was perpendicular to the tangent of the lower border of the mandible was traced, and the cortical width was measured at this point. $\mathrm{MI}$ values lower than 3,1 $\mathrm{mm}$ correspond to bone alteration.

\section{Image analysis}

A calibrated observer performed the images evaluation after previous training, in two different times and with an interval of one week between the two readings.

The Mental Index measures were determined by XoranCAT ${ }^{\circledR}$ linear measurement tools (Xoran Technologies, USA) (figure 1).

\section{Statistical analysis}

The data was tabulated in an Excel 2011 worksheet (Microsoft Corp., USA) and submitted to statistical analysis in BioEstat $5.0^{\circledR}$ software for Windows, with a significance level of $95 \%(p<0.05)$.

To evaluate the reproducibility of the intra-examiner readings (times 1 and 2), an Intraclass Correlation (ICC) Test for quantitative data was performed. 


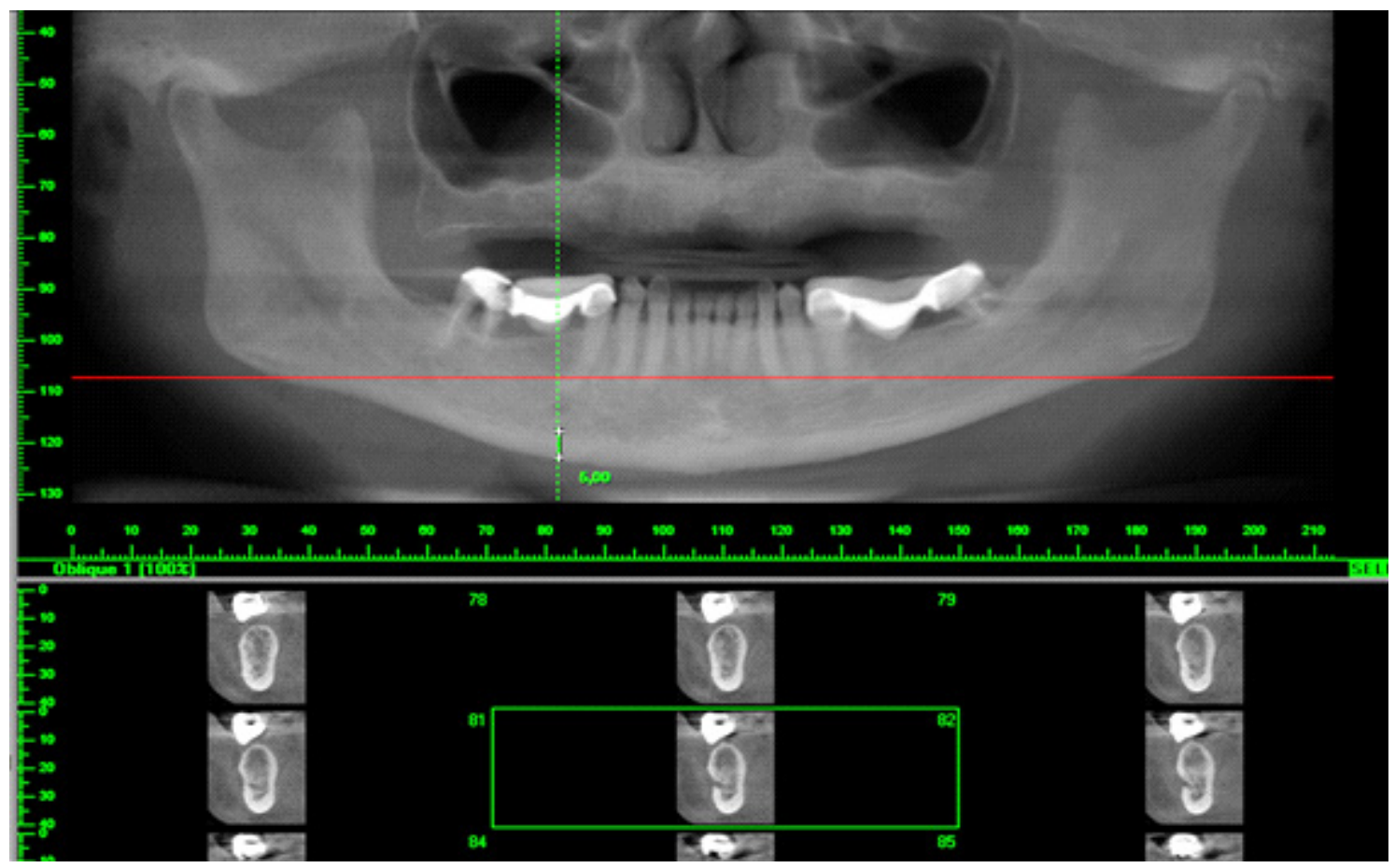

Figure 1. Panoramic reconstruction showing the Mental Index measurement on Software XoranCAT ${ }^{\circledR}$.

For the analysis of the $\mathrm{MI}$ measurements, the t-test was used to compare the averages of the left and right sides in each group studied. The t-test was also used to assess if there were significant differences between the two groups (group W and group M).

Fisher's exact test was used to evaluate the association of bone alterations between the two groups.

\section{RESULTS}

The results showed that the mean age for each group was $48.46 \pm 15.3$ for group $W$ and $53.87 \pm 13.09$ for group M.
Table 1 shows that there were no statistically significant differences on the $\mathrm{Ml}$ obtained from the right and left sides, on the two groups evaluated.

Table 2 shows the comparison results of $\mathrm{Ml}$ between the two groups, showing that there was a statistically significant difference between them.

Table 3 shows that, by Fisher Exact test, there was no association between bone alteration and the two groups studied.

Intraclass correlation test (ICC) used to evaluate the reproducibility of the $\mathrm{Ml}$ measurements showed a good to medium reproducibility (0.40).

Table 1. T-test for comparison of $\mathrm{Ml}$ on right and left sides of the studied groups.

\begin{tabular}{lrrr}
\hline Mental Index (MI) & \multicolumn{1}{c}{$\begin{array}{c}\text { Ml right } \\
\text { mean } \pm \text { SD }\end{array}$} & $\begin{array}{c}\text { Ml left } \\
\text { mean } \pm \text { SD }\end{array}$ & p value \\
\hline Women & $4,19 \pm 0,79$ & $4,10 \pm 0,84$ & 0,50 \\
\hline Men & $5,10 \pm 1,01$ & $5,32 \pm 1,13$ & 0,22 \\
\hline
\end{tabular}

Table 2. Test $t$ for comparison of Ml between the groups studied

\begin{tabular}{lccc}
\hline Mental Index (MI) & Women & Men & $p$ Value \\
Mean \pm SD & $4,150 \pm 0,97$ & $5,214 \pm 1,075$ & $0,0001^{*}$ \\
\hline
\end{tabular}


Table 3. Association between bone alteration in men and women.

\begin{tabular}{lccc}
\hline Ml & Alteration & Normal & P value \\
\hline Men & 0 & $39(100 \%)$ & 0,4935 \\
\hline Women & $2(5,12 \%)$ & $37(94,88 \%)$ & \\
\hline
\end{tabular}

\section{DISCUSSION}

The present study aimed to evaluate the sexual dimorphism through the application of the mental index (MI) on CBCT images, since the literature shows that radiomorphometric indices (RI) may be a viable alternative in studies of bone alterations.

Studies using $\mathrm{Rl}$ in panoramic radiographic images are extensive in the literature [8-11]. In our study, we used panoramic reconstructions obtained from axial sections of CBCT images to apply these indices, since this reconstruction simulates a panoramic radiographic image, and with tools regarding the thickness of the tomographic sections, we can obtain an image that is similar to a panoramic radiograph. In the present study, the thickness of the panoramic reconstruction was set at $20 \mathrm{~mm}$.

CBCT images have been increasingly used for diagnosis and planning in dentistry, and studies assessing the applicability of RI on CBCT images are still relatively rare in the literature, and the vast majority of them evaluate bone alterations in women with osteoporosis [6,12-14].

Koh \& Kim [6] were the first authors to study the use of Computed Tomography Indices (CTI) on CBCT images to assess bone mineral density (BMD) in postmenopausal women, and concluded that these indices can be used for the tracing of osteoporotic women. Mostafa et al. [14] evaluated the application of three different CTI on CBCT images, concluding that these indices can be used as an adjuvant tool to refer patients at risk of osteoporosis for further assessment.

It is known that women, during the climacteric period, begin to present hormonal changes that can lead to a decrease in BMD, which can lead to problems such as osteopenia and osteoporosis. Early detection of these alterations is essential to avoid the occurrence of bone fractures $[1,15]$. A study showed that women who are in the postmenopausal phase usually have $\mathrm{Ml}$ values lower than $3.1 \mathrm{~mm}$, which means, they have lower cortical bone thickness when compared to premenopausal women [15].

Our results showed that there were no statistically significant differences in the means of $\mathrm{Ml}$ in the right and left sides of the patients, in the two groups studied. However, when comparing the averages obtained in each group, we found statistically significant differences, revealing that the mean $\mathrm{Ml}$ in women was lower $(\mathrm{p}<0.05)$ than the mean $\mathrm{Ml}$ in men.

Bozdag \& Sener [16] evaluated radiomorphometric indices applied on panoramic radiographs of men and women, concluding that the Ml did not change with the increase of the age in men, but decreased significantly in women. Knezovic Zlataric et al. [17] showed that there was a decrease on the Ml mean in both genders up to 75 years, but from this age on, the Ml values in women were relatively smaller when compared to men.

The fact that $\mathrm{Ml}$ is lower on women over 50 years agrees with the literature $[9,10,17]$, which can be explained by BMD loss that they suffer after the fifth decade of life. However, our study used women aged 20 years and older, and we concluded that, in general, women had lower cortical bone thickness than men, with anatomical differences between men and women being a possible justification. Although these differences are already expected, in the literature, there is still no study showing the effectiveness of $\mathrm{Ml}$ in determining sexual dimorphism when applied to CBCT images.

Our results also indicated that in the sample studied, there was no association between bone changes in men and women $(p=0.4935)$, and that only $5.12 \%$ of the women in this study were classified as $\mathrm{Ml}<3.1 \mathrm{~mm}$.

We also emphasize that after the proper training of the evaluator for the $\mathrm{MI}$ application on CBCT images, the reproducibility achieved was average to good, meaning that the methodology is not difficult to be applied and can be used by dentists in their office routines, as a way of screening patients with bone alterations.

\section{CONCLUSION}

We can conclude that it is possible to determine sexual dimorphism through the application of $\mathrm{Ml}$ on 
panoramic reconstruction images of $C B C T$, but studies evaluating more patients are necessary to effectively verify the differences between the thicknesses of the mandibular cortical bone of men and women.

\section{Collaborators}

ALE CARNEIRO analyzed the data and wrote the manuscript. SES MACIEL and DMRA SALGADO performed the experiments and wrote the first draft of the manuscript. JRM ZAMBRANA analyzed the data. NRM ZAMBRANA critically reviewed the manuscript for important intellectual content. C COSTA designed the study and analyzed the data. All authors discussed the results and commented on the manuscript at all stages. The manuscript was read and approved by all authors.

\section{REFERENCES}

1. Bollen AM, Taguchi A, Hujoel PP, Hollender LG. Case-control study on self-reported osteoporotic fractures and mandibular cortical bone. Oral Surg Oral Med Oral Pathol Oral Radiol Endod. 2000;90(4):518-24. http://dx.doi.org/10.1067/moe. 2000.107802

2. Taguchi A, Suei Y, Ohtsuka M, Otani K, Tanimoto K, Ohtaki $M$. Usefulness of panoramic radiography in the diagnosis of postmenopausal osteoporosis in women. Width and morphology of inferior cortex of the mandible. Dentomaxillofac Radiol. 1996;25(5):263-7. http://dx.doi. org/10.1259/dmfr.25.5.9161180

3. Devlin H, Horner K. Mandibular radiomorphometric indices in the diagnosis of reduced skeletal bone mineral density. Osteoporos Int. 2002;13(5):373-8. http://dx.doi.org/10.1007/ s001980200042

4. Hua Y, Nackaerts O, Duyck J, Maes F, Jacobs R. Bone quality assessment based on cone beam computed tomography imaging. Clin Oral Implants Res. 2009;20(8):767-71. https:// doi.org/10.1111/j.1600-0501.2008.01677.x

5. Homolka P, Beer A, Birkfellner W, Nowotny R, Gahleitner A, Tschabitscher $M$, et al. Bone mineral density measurement with dental quantitative CT prior to dental implant placement in cadaver mandibles: pilot study. Radiology. 2002;224(1):247-52. https://pubs.rsna.org/doi/10.1148/radiol.2241010948

6. Koh KJ, Kim KA. Utility of the computed tomography indices on cone beam computed tomography images in the diagnosis of osteoporosis in women. Imaging Sci Dent. 2011;41(3):101-6. https://doi.org/10.5624/isd.2011.41.3.101

7. Verma S, Mahima VG, Patil K. Radiomorphometric analysis of frontal sinus for sex determination. J Forensic Dent Sci. 62014.

\section{p. 177-82. http://dx.doi.org/10.4103/0975-1475.137052}

8. Bajoria AA, Ml A, Kamath G, Babshet M, Patil P, Sukhija P. Evaluation of Radiomorphometric Indices in Panoramic Radiograph - A Screening Tool. Open Dent J. 2015;9:303-10. http://dx.doi.org/10.2174/1874210601509010303

9. Dutra V, Yang J, Devlin H, Susin C. Radiomorphometric indices and their relation to gender, age, and dental status. Oral Surg Oral Med Oral Pathol Oral Radiol Endod. 2005;99(4):479-84. https://doi.org/10.1016/j.tripleo.2004.09.013

10. Ledgerton D, Horner $K$, Devlin $H$, Worthington $H$. Radiomorphometric indices of the mandible in a British female population. Dentomaxillofac Radiol. 1999;28(3):173-81. http:// dx.doi.org/10.1038/sj/dmfr/4600435

11. Tayebi A, Tofangchiha M, Fard MA, Gosili A. The relationship of mandibular radiomorphometric indices to skeletal age, chronological age and skeletal malocclusion type. J Clin Exp Dent. 2017;9(8):e970-e5. http://dx.doi.org/10.4317/jced.53 819

12. Diniz-Freitas M, Fernandez-Montenegro P, Fernandez-Feijoo J, Limeres-Posse J, Gonzalez-Mosquera A, Vazquez-Garcia E, et al. Mandibular cortical indices on cone-beam computed tomography images in osteoporotic women on treatment with oral bisphosphonates. Gerodontology. 2016;33(2):155-60. http://dx.doi.org/10.1111/ger.12121

13. Gungor E, Yildirim D, Cevik R. Evaluation of osteoporosis in jaw bones using cone beam CT and dual-energy X-ray absorptiometry. J Oral Sci. 2016;58(2):185-94. http://dx.doi. org/10.2334/josnusd.15-0609

14. Mostafa RA, Arnout EA, Abo el-Fotouh MM. Feasibility of cone beam computed tomography radiomorphometric analysis and fractal dimension in assessment of postmenopausal osteoporosis in correlation with dual X-ray absorptiometry. Dentomaxillofac Radiol.45(7). http://dx.doi.org/10.1259/ dmfr.20160212

15. Taguchi A, Tsuda M, Ohtsuka M, Kodama I, Sanada M, Nakamoto T, et al. Use of dental panoramic radiographs in identifying younger postmenopausal women with osteoporosis. Osteoporos Int. 2006;17(3):387-94. http://dx.doi. org/10.1007/s00198-005-2029-7

16. Bozdag G, Sener S. The evaluation of $\mathrm{MCl}, \mathrm{MI}, \mathrm{PMI}$ and GT on both genders with different age and dental status. Dentomaxillofac Radiol. 2015;44(9):20140435. http://dx.doi. org/10.1007/s00198-005-2029-7

17. Knezović Zlatarić D, Celebić A, Lazić B, Baucić I, Komar D, Stipetić-Ovcaricek J, Ibrahimagić L. Influence of age and gender on radiomorphometric indices of the mandible in removable denture wearers. Coll Antropol. 2002;26(1):259-66. http://dx.doi.org/10.1038/sj/dmfr/4600435

Received on: 28/11/2018 Final version resubmitted on: 14/3/2019 Approved on: 15/4/2019 